\title{
THE NUMERICAL EXAMPLE FOR EVALUATING THE CRITERIA DESCRIBING THE QUALITY OF THE TRIP BY INTERNATIONAL TRAIN
}

\author{
Henrikas Sivilevičius, Lijana Maskeliūnaitè
}

\section{Introduction}

The main criteria, describing the development of railway systems refer to traffic safety, sustainability, competitiveness as well as quality and variety of services provided to passengers.

In the new age of railway transportation, the main task is to ensure a safe use of railway infrastructure, which should meet the requirements of safety standards. A set of programmes most suitable for ensuring railway track safety were developed [26]. A bottleneck optimization model to increase the carrying capacity by reasonably arranging routes and turnouts, and considering proportionality and minimization of total occupation time was offered [12]. A simplified approach to assessing the initial fire development and spread in passenger rail vehicles was suggested [16], and the development of the next generation of intercity corridor bi-level equipment with crash energy management was described [13]. The hunting stability and derailment analysis of a carriage model of a railway vehicle system was performed [1], and a short-range prediction model for track quality index was offered [27].

The economic impacts of intercity passenger rail service (evidence from passenger surveys) [23] and optimal train operation for minimum energy consumption, considering track alignment speed limit, and schedule adherence were analysed [7]. Cluster analysis of intercity rail passengers in emerging high-speed rail corridor was performed [24] and rail transit travel time reliability and estimation of passenger route choice behaviour (the analysis using automatic fare collection data) were described [25]. The value for railway capacity, assessing the efficiency of operators in Great Britain was determined [20], and the development of base train equivalents to standardize trains for capacity analysis was described [9]. A comprehensive decision support framework of strategic railway capacity planning was developed [8]. Over the preceding years, transit agencies in the United States have been building light rail transit (LRT) or bus rapid transit (BRT) systems to provide an effective and reliable high-speed transit service. However, the selection between LRT and BRT has been controversial for many years, with no suitable closure. A cost estimating model was developed for LRT and bus rapid transit BRT systems to better aid transportation planners and decision makers in the selection [6].

Public rail transport planning is a highly complex task, and it is divided into several steps: analysis of demand, line planning, train scheduling planning, planning of rolling stock, and crew management. A train routing model combined with a train scheduling problem, which is a $0-1$ mixed-integer nonlinear programming problem, was offered [10]. Transportation infrastructure management is a decisionmaking process concerning the allocation of resources for maintenance, rehabilitation, and reconstruction of facilities composing transportation systems. Numerical experiments were presented to examine the effects of economic and functional interdependencies on network optimization and demonstrate the validity of the proposed model [4]. The railway blocking problem (RBP) solution is important for freight 
railway companies. A mathematical model was presented for the RBP by Iran Railways. Solving the blocking problem considerably reduces the operational cost of railways and saves time in moving the freights [28]. The configuration of service facilities, such as ticket vending machines, staffed ticket booths, automatic fare gates, and escalators, is an important issue for planning and design of rail transit stations. Reasonable configuration of service facilities is based on thorough understanding of passenger traffic characteristics of these service facilities, which are affected by passenger characteristics, station types, and facility performance. The traffic characteristics of service facilities were analysed and the influencing factors (for example, station types, passenger gender, and passenger experience) were considered [11].

Also, it is very important to control complicated processes, the analysis of activities, aims and tasks, as well as methods of their fulfilment, in order to be performed. The influence of various factors on work efficiency and quality should be also evaluated. To make effective decisions in technological and management, engineering economics areas, etc., AHP, TOPSIS and TOPSIS grey, FAHP [31], [32], [5], [29], [30], SAW and COPRAS [18] method are commonly used.

\section{Passenger Services}

In 2012, joint-stock company (JSC) "Lithuanian Railways" (AB "Lietuvos geležinkeliai" - "LG") passenger trains operated on 52 domestic lines and on 18 international lines: 183 trains on domestic lines and 4 trains (made up by the company) on international lines. A total of 22 trains of the railway undertakings from other countries came to Lithuania or passed the territory of this country in transit.

Compared to 2011, passenger revenues had risen by $5.9 \%$ in 2012 (Fig. 1) [17].

\section{Fig. 1: Passenger revenues in 2011-2012 (mil)}

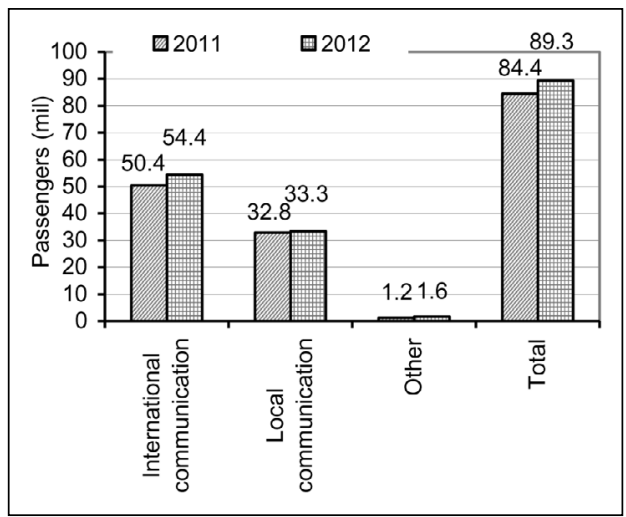

Source: Metinè ataskaita. (Annual report) 2012

Within the framework of the passenger loyalty programme different discounts on tickets were offered and campaigns conducted in 2012: a $20 \%$ discount was applied during holidays (Cristmas, Easter, St. John's Day etc.), and a $30 \%$ discount on tickets was applied during a campaign targeted at the young people aged 10-26 to travel by train at reduced prices [17].

\section{Tab. 1: Passenger flows in 2008-2012}

\begin{tabular}{l|c|c|c|c|c}
\multicolumn{2}{c|}{} & \multicolumn{5}{c}{ Year } \\
\cline { 2 - 6 } & $\mathbf{2 0 0 8}$ & $\mathbf{2 0 0 9}$ & $\mathbf{2 0 1 0}$ & $\mathbf{2 0 1 1}$ & $\mathbf{2 0 1 2}$ \\
\hline Payload quantity, mil passengers & 5.1 & 4.4 & 4.4 & 4.7 & 4.8 \\
\hline local & 4.1 & 3.5 & 3.5 & 3.8 & 3.8 \\
\hline international & 1.0 & 0.9 & 0.9 & 0.9 & 1.0 \\
\hline Revenue passenger kilometres, mil & 397.5 & 357.0 & 373.1 & 389.1 & 403.2 \\
\hline local & 235.3 & 213.4 & 225.6 & 248.5 & 254.5 \\
\hline international & 162.2 & 143.6 & 147.5 & 140.6 & 148.7 \\
\hline Average distance per passenger, km & 78.5 & 81.6 & 85.5 & 83.6 & 84.0 \\
\hline Average number of trips per inhabitant of the country & 2 & 1 & 1 & 1 & 2 \\
\hline
\end{tabular}


As shown in Table 1, the flows of passengers hardly changed.

Passenger revenues accounted for $5.1 \%$ in the total revenue structure in 2012, a rise of $5.9 \%$ over the previous year. This was due to the increased passenger flows on international lines [17], especially on the route Vilnius-Minsk -Vilnius where passenger flows grew twofold.

\section{Practical Application of the Model}

The quality of travel by train (QTT) is described by both qualitative and quantitative criteria. It would be convenient to quantitatively evaluate the significance of all the criteria for QTT by a single number. The significance of particular criteria differs to some extent. In the work [15], 49 QTT criteria belonging to four various groups A, B, C, D (Fig. 2) are considered. Their average weights are determined by using the expert evaluation method. The weights of 16 criteria, belonging to group $A$, and describing the train elements and technical state of rails (railway track), were obtained from the survey of experts, when three categories of respondents - passengers $(P)$ and experts, including the service staff of the train (ST) and the administration staff (AS) of the joint-stock company 'Lithuanian Railways' (AB „Lietuvos geležinkeliai“ - "LG”), provided their judgements.

The model for calculating the criteria, describing the train elements and technical state of the railway track based on the mean weight $\bar{Z}_{A}^{*}$ and the mean weight of each criterion $\bar{Q}_{A j}$ (expressing the estimates of the significance of group A criteria, elicited from all three categories of respondents and experts) is expressed by the equation:

$$
\begin{gathered}
K_{A}=\bar{Z}_{A}^{*}\left(\bar{Q}_{A 1} \times x_{A 1}+\bar{Q}_{A 2} \times x_{A 2}+\ldots+\right. \\
\left.+\bar{Q}_{A 16} \times X_{A 16}\right),
\end{gathered}
$$

where $K_{A}$ is a comprehensive quality index (CQI) of the international train (ranging from 0 to 1$) ; \bar{Z}_{A}^{*}$ is the mean weight, reflecting the quality

\begin{tabular}{|l|}
\hline \multicolumn{1}{|c|}{ THE CRITERIA OF RAILWAY TRIP QUALITY } \\
\hline A. The criteria describing the train elements and the technical state of the railway track \\
\hline C. The criteria describing the cost of the trip and the provided services [14] \\
\hline \hline A1. Quality of the railway track \\
\hline \hline A2. Speed of the train (trip duration) \\
\hline A3. The state of the carriage exterior (cleanness, deformations, damage, etc.) \\
\hline \hline A4. Noise reduction measures (noise insulation) \\
\hline \hline A5. The interior of a passenger carriage \\
\hline \hline A6. Operation of ventilation, air conditioning, cooling and lighting systems in terms of their timely switching on/off \\
\hline \hline A7. Temperature required inside a passenger carriage \\
\hline \hline A8. Type (ordinary or vacuum) and condition of toilets (lavatories) \\
\hline \hline A9. Construction of berths (safety belts on upper level berths), special facilities for the disabled \\
\hline \hline A10. Availability of regularly operating shower \\
\hline \hline A11. Special compartments for transporting bicycles \\
\hline \hline A12. Smoking places \\
\hline \hline A13. Radio broadcasting unit and its centralized operation (switching on/off) \\
\hline \hline A14. Dining-car (buffet-car) \\
\hline \hline A15. Possibility of calling an attendant to a passengers' compartment in emergency cases \\
\hline \hline A16. Possibility of using electrical appliances (hairdryer, iron, etc.) \\
\hline
\end{tabular}


respondents' and experts' estimates of the significance of group $A$ criteria; $\bar{Q}_{A 1}, \ldots, \bar{Q}_{A m}$ denote the mean weight values of $j$-th criterion of group $A(1, \ldots, m)$ determined by the expert evaluation method [21], [14] $x_{A 1}, \ldots, x_{A m}$ are the variables of $j$-th criterion of group $\mathrm{A}(1, \ldots, m)$, whose estimates are used for determining the real criterion value, ranging from 0 to 1 .

The multicriteria index $K_{A}$ [15], describing the criteria associated with the train elements and railway track condition, is calculated by the additive equation 2 .

$$
\begin{aligned}
& K_{A}=\bar{Z}_{A}^{*} \cdot\left(\overline { Q } _ { A 1 } \cdot \left[0.997+0.00245 \cdot \frac{\sum_{s=1}^{N_{k m}} T Q I_{f s}}{N_{k m}}-0.000962 \cdot\left(\frac{\sum_{s=1}^{N_{k m}} T Q I_{f s}}{N_{k m}}\right)^{2}+1.532 \cdot 10^{-5}\right.\right.
\end{aligned}
$$

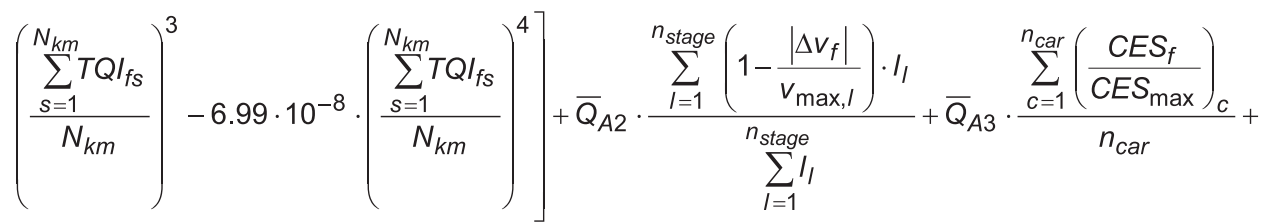

$$
\begin{aligned}
& \bar{Q}_{A 4} \cdot\left(1-\frac{\sum_{c=1}^{n_{c a r}}\left(\frac{N L_{f}}{N L_{\max }}\right)_{C}}{n_{c a r}}\right)+\bar{Q}_{A 5} \cdot \frac{\sum_{c=1}^{n_{c a r}}\left(\frac{C l_{f}}{C l_{\max }}\right)_{C}}{n_{c a r}}+\bar{Q}_{A 6} \cdot \frac{\sum_{c=1}^{n_{c a r}}\left(\frac{V C L_{f}}{V C L_{\max }}\right)_{C}}{n_{c a r}}+\bar{Q}_{A 7} \cdot\left(1-\left.\frac{\sum_{c=1}^{n_{c a r}} \mid \frac{T_{U}+T_{D}}{2}-\bar{T}_{f}}{T_{U}-T_{D}}\right|_{C} \mid+\right. \\
& \bar{Q}_{A 8} \cdot \frac{\sum_{c=1}^{n_{c a r}}\left(\frac{W C_{f}}{W C_{\max }}\right)_{c}}{n_{c a r}}+\bar{Q}_{A 9} \cdot \frac{\sum_{c=1}^{n_{c a r}}\left(\frac{P B_{f}}{P B_{\max }}\right)_{C}}{n_{c a r}}+\bar{Q}_{A 10} \cdot \frac{\sum_{c=1}^{n_{c a r}}\left(\frac{S_{f}}{S_{\max }}\right)_{c}}{n_{c a r}}+\bar{Q}_{A 11} \cdot \frac{T B_{f}}{T B_{\max }}+\bar{Q}_{A 12} \cdot \frac{S P_{f}}{S P_{\max }}+ \\
& \left.\bar{Q}_{A 13} \cdot \frac{\sum_{c=1}^{n_{c a r}}\left(\frac{R_{f}}{R_{\max }}\right)_{C}}{n_{c a r}}+\bar{Q}_{A 14} \cdot \frac{D C_{f}}{D C_{\max }}+\bar{Q}_{A 15} \cdot \frac{\sum_{c=1}^{n_{c a r}}\left(\frac{A C_{f}}{A C_{\max }}\right)_{C}}{n_{c a r}}+\bar{Q}_{A 16} \cdot \frac{H I_{f}}{H I_{\max }}\right)
\end{aligned}
$$

where $K_{A}$ is a comprehensive quality index (CQI) of the international train (ranging from 0 to 1 ); $\bar{Z}_{A}^{*}$ is the mean weight, reflecting the respondents' and experts' estimates of the significance of group A criteria; $\bar{Q}_{A 1}, \ldots, \bar{Q}_{A m}$ denote mean weight values of $j$-th criterion of group $A(1, \ldots, m)$ determined by the expert evaluation method; $T Q I_{f}$ is the real track quality index TQI for the whole railway track determined by the track geometry car; $N_{k m}$ is the total length of the railway track, $\mathrm{km}(\mathrm{s}=1$, $\left.2, \ldots, N_{k m}\right) ; n_{\text {stage }}$ is the number of railway track sections between stations $(I=1,2, \ldots, r) ; \Delta v_{f}$ is the real and the highest allowable speed difference of the train at the l-th section of the distance between two stations, $\mathrm{km} / \mathrm{h} ; v_{\max }$ is the highest allowable speed of a train at the 1 -th section of a journey, $\mathrm{km} / \mathrm{h} ; \mathrm{I}$, denotes the lengths of the sections of a journey, $\mathrm{km} ; C E S_{f}$ is the real condition (cleanness, damages) of the $c$-th carriage expressed in points $(0,1$ or 2 points); $C E S_{\text {max }}$ is the highest estimate value of the carriage in points (2 points); $n_{c a r}$ is the number of carriages in the train $(c=1,2, \ldots$, $\left.n_{c a r}\right) ; N L_{f}$ is the real noise level in the $c$-th carriage, dBA; $N L_{m a x}$ a is the allowable noise level in the $c$-th carriage, $\mathrm{dBA} ; \mathrm{Cl}_{f}$ is the real estimate of the c-th carriage interior in points 
(0, 1 or 2 points); $C I_{\max }$ is the maximum allowable carriage interior estimate value in points (2 points); $V C L_{f}$ is the estimate (in points) of the operation of the $c$-th carriage systems $\left(0,1,2,3\right.$ or 4 points ); $V C L_{\text {max }}$ is the highest possible estimate of the systems operating in the carriage (4 points); $T_{D}$ is the lowest allowable carriage temperature, ${ }^{\circ} \mathrm{C}$. In winter, when solid fuel is burned and the outdoor temperature is not lower than $-40^{\circ} \mathrm{C}$ and not higher than $+10^{\circ} \mathrm{C}, T_{D}=18{ }^{\circ} \mathrm{C}$, while when water is heated by electricity, $T_{D}=20^{\circ} \mathrm{C}$ (the temperature of $(22 \pm 2){ }^{\circ} \mathrm{C}$ should be automatically maintained). In summer, when air-conditioning is used, the temperature of $(24 \pm 2){ }^{\circ} \mathrm{C}$ should be automatically maintained, therefore, $T_{D}=22{ }^{\circ} \mathrm{C}$ [3]; $T_{U}$ is the highest allowable temperature inside a passenger carriage $\left(+26{ }^{\circ} \mathrm{C}\right)$. In winter, when the outdoor temperature is not lower than $-40{ }^{\circ} \mathrm{C}$ and solid fuel is used for heating, $T_{U}=+22{ }^{\circ} \mathrm{C}$, while when water is heated by electricity, $T_{U}=24^{\circ} \mathrm{C}$ (the temperature of $(22 \pm 2){ }^{\circ} \mathrm{C}$ should be automatically maintained); $\bar{T}_{f}$ is the average temperature in the $c$-th carriage, measured $n_{T}$ times at various places of the carriage during the trip (equation 4); $W C_{f}$ is the estimate of the real condition of lavatories in the c-th carriage, expressed in points $(0,1,2,3$ or 4 points); $W C_{\max }$ is the highest possible estimate (in points) of the c-th carriage (4 points); $P B_{f}$ is the estimate in points $(0,1,2,3$ or 4 points) of the berth structure in the $c$-th carriage (the availability of safety belts on the upper level berths) and the adaptation of a passenger carriage for the disabled passengers; $P B_{\max }$ is the highest possible estimate (4 points) of the berth structure (the availability of safety belts on the upper level berths) and the adaptation of a passenger carriage for the disabled passengers; $S_{f}$ is the estimate of shower equipment availability and its work hours in the $c$-th carriage in points ( 0,1 or 2 points); $S_{\text {max }}$ is the highest possible estimate of shower equipment availability and its work hours (2 points); $T B_{f}$ means the presence or absence of a special carriage or compartment for carrying bicycles in the train and the evaluation of transportation conditions in points $(0,1,2$ or 4 points); $T B_{\max }$ is the highest estimate of the conditions for carrying bicycles in the train (4 points); $S P_{f}$ is the estimate of smoking places in the train in points $\left(0,1\right.$ or 2 points); $S P_{\text {max }}$ is the highest possible estimate of smoking places in the train (2 points); $R_{f}$ is the estimate in points $(0,1,2,3$ or 4 points) of operation of the radio broadcasting unit in the $c$-th carriage and its centralized on/off switching; $R_{\max }$ is the highest possible estimate of the radio broadcasting unit operation and centralized on/off switching (4 points); $D C_{f}$ is the estimate of the dining car availability and the provided services in points $\left(0,1,2,3,4,5,6,7\right.$ or 8 points); $D C_{\max }$ is the highest possible estimate of the dining car availability and the provided services (8 points); $A C_{f}$ is the estimate in points $(0,1$ or 2 points) of the possibility to call the conductor to a passenger's compartment of the $c$-th carriage in the case of emergency; $A C_{\max }$ is the highest possible estimate of the possibility to call the conductor to a passenger's compartment in the case of emergency (2 points); $H I_{f}$ is the estimate of the possibility for passengers to use a hairdryer and an iron in the train expressed in points $\left(0,1,2,3\right.$ or 4 points); $H I_{\text {max }}$ is the highest estimate of the possibility for passengers to use a hairdryer and an iron in the train (4 points).

Based on the considered model and real research data, as well as the allowable or best values of each criterion, the significance of the criteria of group A for evaluating the quality of passenger transportation by train by a single value may be obtained.

Using the formulas suggested in the paper, all CQI components (16 criteria) and their significance may be calculated based on the real data taken from standards, technical specifications and other reliable sources. The testing was performed on the train 'Vilnius-Moscow'.

Quality of the railway track. The jointstock company 'Lithuanian Railways' ("LG") uses a self-propelled geometry car EM-140 made in 2009 by the Plasser\&Theurer company (Austria) for measuring geometrical parameters of the railway track. The geometrical railway track parameters measured by the geometry car and stored on a storage device are as follows: gauge, mutual position of the rails with respect to the rail head level, the rails' dents, the position of the rails in the plan view, curves' radii, misalignments, the allowable speed on the curve of a railway, elevation of the slope of the outer rail and the longitudinal slope of the railway track. All geometrical railway track 
parameters are obtained by precise measuring of the spatial curve of the track.

On the route Vilnius-Moscow, the total length of which is $944 \mathrm{~km}$, the railway double track, running on the territory of Lithuanian Republic from Vilnius to the frontier with Belarus at Kena, makes $36 \mathrm{~km}$. The average $\overline{T Q}_{l}$, measured by a geometry car in January, 2012 for the railway track running through Vilnius-Kena-State frontier, was calculated by the formula based on $T Q I_{f s}$ of all one-kilometre track lengths as follows:

$$
{\overline{T Q I_{f}}}_{f}=\frac{\sum_{s=1}^{N_{k m}} T Q I_{f s}}{N_{k m}},
$$

where $T Q I_{f s}$ is quality index of the $s$-th $1 \mathrm{~km}$ track length, with the numerical value equal to the total variance (the sum of $\sigma_{g}^{2}$ ) of separate $g$-th track geometrical parameters, $\mathrm{mm}^{2}(\mathrm{~s}=1$, $\left.2, \ldots, N_{k m} ; \mathrm{g}=1,2, \ldots, 7\right) ; N_{k m}$ is the total track length, $\mathrm{km}$.

The total TQI of all track lengths making $36 \mathrm{~km}$ on the route Vilnus-Kena-State frontier (with Belarus) is $\sum_{s=1}^{36} T Q l_{f s}=903.2 \mathrm{~mm}^{2}, N_{k m}=36 \mathrm{~km}$, o $\overline{T Q}_{4}=25.09 \mathrm{~mm}^{2}$. The smallest $T Q l_{\text {fmin }}$ value obtained for $1 \mathrm{~km}$ track length was $T Q I_{\text {fmin }}=$ $=14.95 \mathrm{~mm}^{2}$, while the largest value was $T Q I_{\text {fmax }}=64.04 \mathrm{~mm}^{2}$.

Based on the standard $T Q I_{\text {norm }}$ (from 0 to $45 \mathrm{~mm}^{2}$ ) and modelled $T Q I_{\text {mod }}$ (from 45 to $90 \mathrm{~mm}^{2}$ ) values, the correlation (with determination coefficient $\mathrm{R}^{2}=0.9961$ ) between the real $T Q I_{f}$ and the variable $x_{A 1}$ of the first group $A$ criterion, showing the effect of the variation of geometric track parameters on the track and trip (by train) quality, has been obtained:

$$
\begin{aligned}
& x_{A 1}=0.997+0.00245 \times \overline{T Q}_{f}-0.000962 \times
\end{aligned}
$$

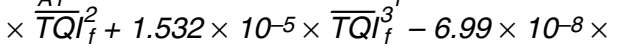

$$
\begin{aligned}
& \times \overline{T Q I}_{f}^{4} \text {. }
\end{aligned}
$$

Given the average $\overline{T Q} l_{f}=25.09 \mathrm{~mm}^{2}$ of the track measured by a geometry car, the value $x_{A 1}=0,667$, which was obtained from the regression equation (4), complies with good quality of travel by train, depending on track parameters, determining its quality.
Speed of the train (trip duration). The railway track on the route Vilnius-Kena-state border (with Belarus) consists of 4 sections of a journey (representing the lengths between the stations) (Fig. 3). The total length of the railway track is $L=36 \mathrm{~km}$. The lengths between intermediate stations are $I_{1}=9 \mathrm{~km}, I_{2}=8 \mathrm{~km}$, $I_{3}=12 \mathrm{~km}$ and $I_{4}=7 \mathrm{~km}\left(L=I_{1}+I_{2}+\ldots+I_{1}\right)$. The highest allowable train speed on the route (railway track) Vilnius-state border is $v_{\text {max }, I}=$ $=120 \mathrm{~km} / \mathrm{h}$ [2]. The engine driver had a written instruction that, on May 17, 2012, the train speed on the route Kena-state border had to be limited to $40 \mathrm{~km} / \mathrm{h}$. The real train speed on the sections of the considered railway track was $v_{f 1}=43 \mathrm{~km} / \mathrm{h}, v_{f 2}=77 \mathrm{~km} / \mathrm{h}, v_{f 3}=57 \mathrm{~km} / \mathrm{h}$ and $v_{f 4}=51 \mathrm{~km} / \mathrm{h}$ (the average speed was recorded based on the data provided by the control panel screen of the railway carriage). The CQI component was calculated by equation (2) and $x_{A 2}=0.473$ was obtained. In the ideal case, the train could move at the highest allowable speed $\left(x_{A 2}=1\right)$ on all railway track sections. In the worst case, it could either exceed the highest allowable speed, which is risky (taking into account traffic safety), or move very slowly. Therefore, it is assumed that $\mathrm{x}_{\mathrm{A} 2}=0$.

The condition of passenger carriage exterior (cleanness, deformations, damages, etc.). There are seven railway carriages in the train. All railway carriages are washed before the train departs from the station of its formation, therefore, they are clean. There are no damages on carriages' bodies either. The CQI component was calculated by equation (2) and the maximum $x_{A 3}=1$ was obtained.

Noise reduction measures (noise insulation). On November 24, 2005, the department of passenger servicing of the Directorate for Passenger Transportation by the JSC "Lithuanian Railways" - "LG" specified the equivalent noise exposure level in the train Vilnius-Moscow (for the conditions, when two conductors work in one passenger carriage) to be equal to $72 \mathrm{~dB}(\mathrm{~A})$, fixing it in the card for determining occupational risk. In the dining car of this train, the equivalent noise level at the workplace of the conductor-waiter (a bar) was specified to be $62 \mathrm{~dB}(\mathrm{~A})$ [19]. According to time characteristic, noise produced in the train is variable $(\geq 5 \mathrm{~dB})$. The train has seven railway carriages. The CQI component was calculated 


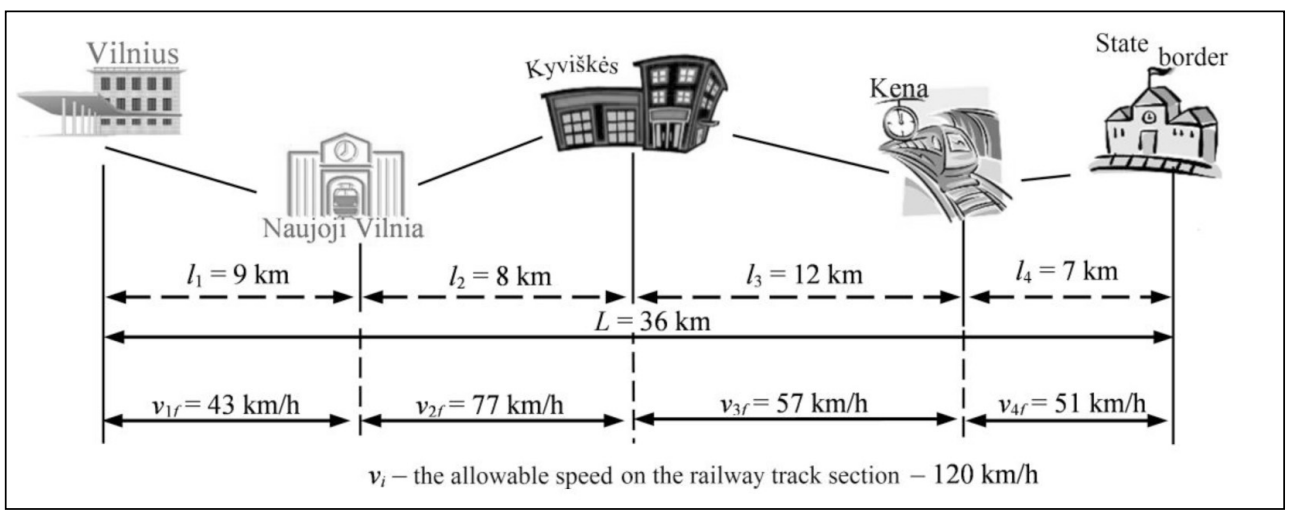

Source: own

by equation (2) and $x_{A 4}=0.188$ was obtained. In the ideal case, the noise level is equal to $0 \mathrm{~dB}(\mathrm{~A})\left(x_{A 4}=1\right)$, while, in the worst case, when the noise level exceeds the limiting noise exposure value, a negative value is obtained. It is considered that $x_{A 4}=0$.

The interior of a passenger carriage. The renewal of the company's rolling stock (particularly, passenger carriages) is performed in two ways: a) the service life of the employed passenger carriages is prolonged (by their modernization); b) new passenger carriages are purchased. To validate the suggested model for evaluating passenger carriage interior and to show its applicability, it was tested in the international train Vilnius-Moscow on November 20, 2010. The train is made up of 7 railway carriages, including 4 new and 3 modernized carriages. The CQI component was calculated by equation (2) and $x_{A 5}=0.786$ was obtained.

Operation of ventilation, air conditioning, cooling and lighting systems in terms of their timely on/off switching. There are seven railway carriages in the train. Air conditioning systems are installed in all railway carriages, running on international routes. In six carriages, all systems, including air conditioning, ventilation, heating and lighting systems, are operating, while, in one carriage, all systems, except for air conditioning system, which has not been installed yet, are operating. The CQI component was calculated by equation (2) and $x_{A 6}=0.964$ was obtained.

Temperature required inside a passenger carriage. The train has seven railway carriages. On March 22 and 24, 2012, the indoor temperature was measured in a fourberth compartment of a sleeping carriage from 4:00 p.m. to 7:00 a.m. Sixty one measurements were made with the interval of 15 minutes in compartments 1 and 9 . The indoor temperature in the carriage was measured by a digital thermometer (TA20) for measuring indoor and outdoor temperature. The ambient air temperature was recorded based on the data displayed on the screen of the control panel of the carriage. The change of the outdoor and indoor temperature is shown in Figs $4(a, b)$.

At the time of measuring (Figs 5 and 6 ), the average outdoor temperature was $7.23^{\circ} \mathrm{C}$ and $3.35^{\circ} \mathrm{C}$, i.e. higher than $-40^{\circ} \mathrm{C}$. It is assumed that the dates of measurement belong to the winter period.

$\bar{T}_{f}$ is the average temperature in the $c$-th carriage, measured $n_{T}$ times at various places of the carriage during the trip:

$$
\overline{T_{f}}=\frac{\sum_{t=1}^{n_{T}} T_{f t}}{n_{T}},
$$


The change of the outdoor and indoor temperature: $a-$ in the passenger carriage compartment 1 (on March 22, 2012); b - in the passenger carriage compartment 9 (on March 24, 2012)
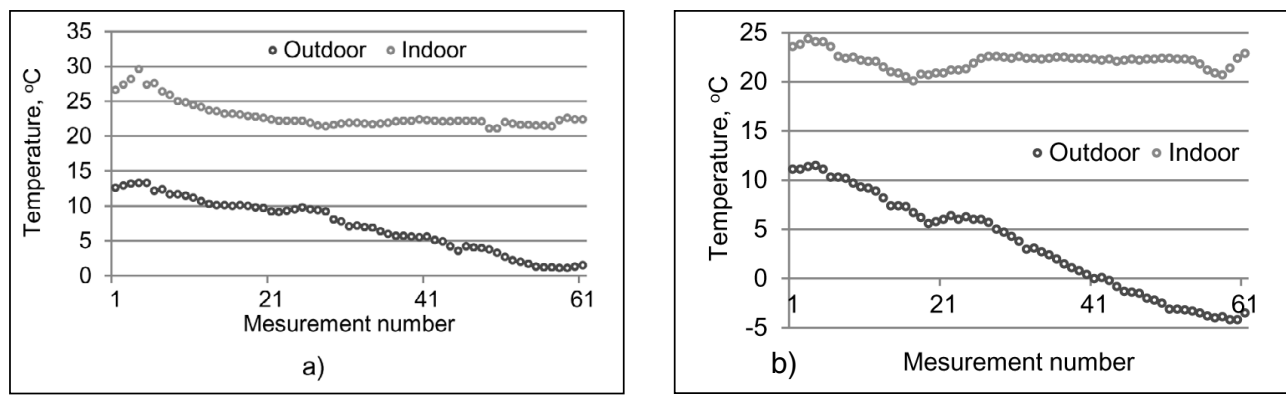

Source: own

\section{Fig. 5:}

The histogram and statistical data of the outdoor (a) and indoor (b) temperature (in the passenger carriage compartment 1), measured on March 22, 2012

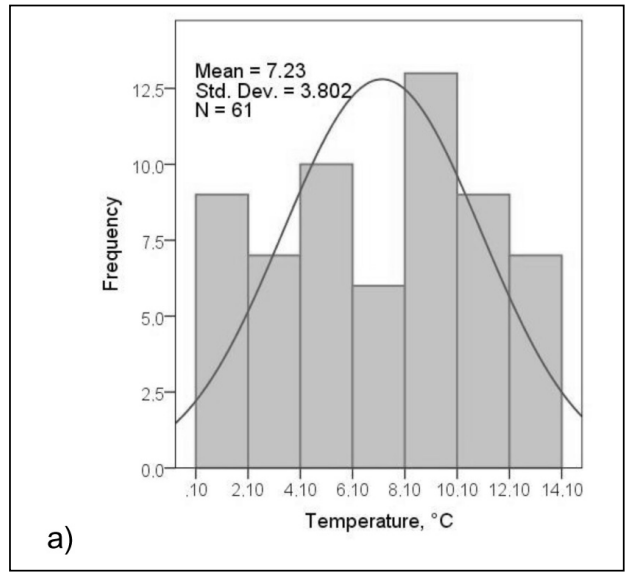

where $T_{f t}$ is the temperature obtained in the $t$-th measurement, ${ }^{\circ} \mathrm{C} ; n_{T}$ is the number of temperature measurements $\left(t=1,2, \ldots, n_{T}\right)$.

The average indoor temperature in the carriage measured on March 22 was $23{ }^{\circ} \mathrm{C}$ (equation 4) $\left(\overline{T_{f}}=\frac{1402.7}{61}=23\right)$ (Fig. 4 (b)), while, on March 24, it was $22{ }^{\circ} \mathrm{C}$

$$
\left(\overline{T_{f}}=\frac{1350.3}{61}\right)=22.14 \text { (Fig. } 6 \text { (b)). By }
$$

interpolating the data from the graph (Fig. 5), the quality level was obtained to be $x_{A 7}=0.750$,

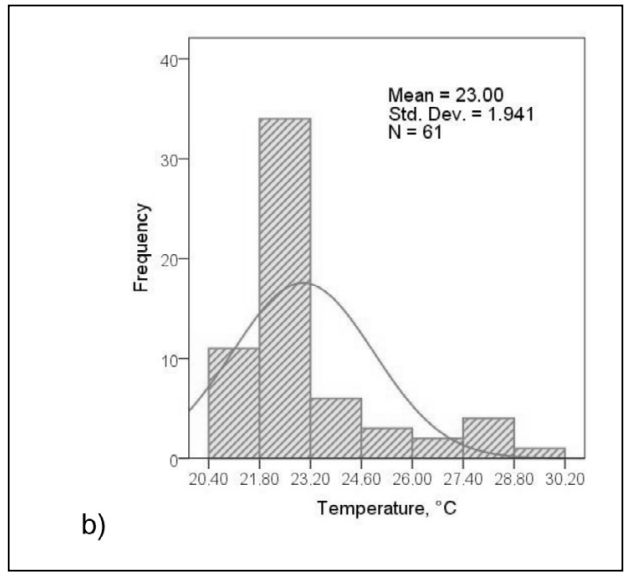

Source: own

while, on the following day (Fig. 6), it was $x_{A 7}=0.965$. The case with real data from equation (2) for winter season was calculated (when water in all passenger carriages was heated by electricity obtained from the highvoltage $(3000 \mathrm{~V})$ overhead contact system). Based on the measurement of the indoor temperature in the compartment 1 (the first day), it was determined that $x_{A 7}=0.75$ ( $T_{U}=24, T_{D}=20, \bar{T}_{f}=23$ ), while for the compartment 9 (the second day) $x_{A 7}=1$ $\left(T_{U}=24, T_{D}=20, \bar{T}_{f}=22\right)$ was obtained. This is an ideal case. 
The limiting case, with $x_{A 7}=0.5$, when $T_{U}=24, T_{D}=20$ and $\bar{T}_{f}=20$, and a critical (not allowable) case, with $x_{A 7}=0$ when $T_{U}=24$, $T_{D}=20$ and $\bar{T}_{f}=18$, are calculated for winter period (when water in all passenger carriages was heated by electricity obtained from the highvoltage (3000 V) overhead contact system).

The worst case $\left(x_{A 7}=0\right)$ is obtained, when $\bar{T}_{f}$ is by $2{ }^{\circ} \mathrm{C}$ lower than the lower allowable limit $T_{D}$, or when $\bar{T}_{f}$ is by $2{ }^{\circ} \mathrm{C}$ higher than the upper allowable limit $T_{U}$. If $\bar{T}_{f}$ is lower than $T_{D}$ by more than $2{ }^{\circ} \mathrm{C}$ or higher than $T_{U}$ by $2{ }^{\circ} \mathrm{C}$, the value of $x_{A 7}$ will be negative. Therefore, it is assumed that $x_{A 7}=0$.

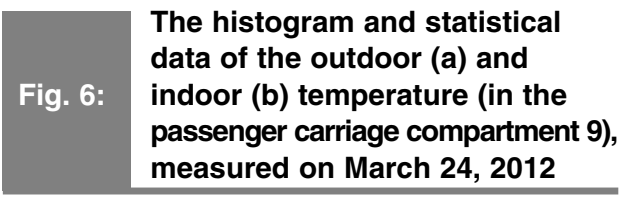

a)

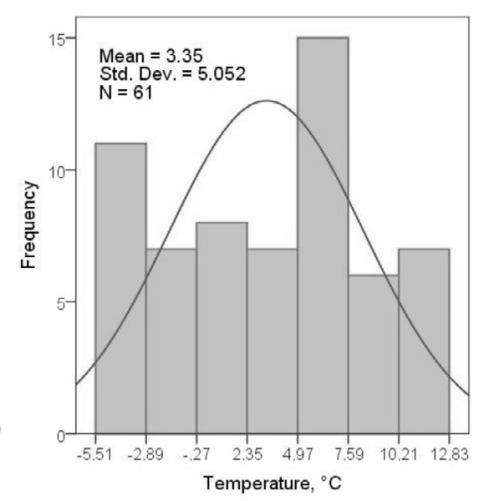

Source: own b)

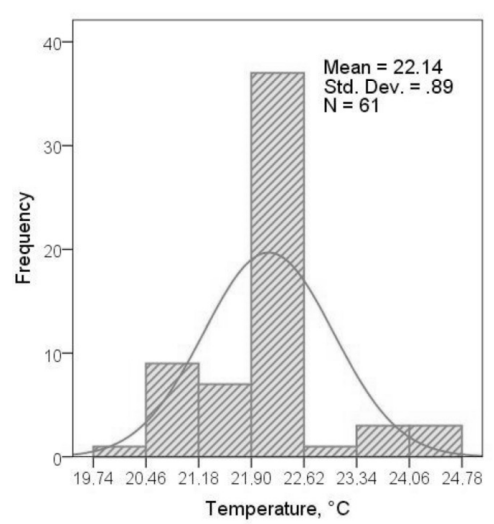

Source: own
Type (ordinary or vacuum) and condition of toilets (lavatories). Now, $70 \%$ of the employed passenger carriages of the "LG" company have vacuum toilets. It is planned that in 2-4 years ecological toilet equipment will be installed in all passenger carriages. The train has seven railway carriages. In six carriages, there are vacuum toilets, which are properly maintained (the head of the train controls their condition), while the toilets in the first car are ordinary, but clean. The CQI component was calculated by equation (2) and $x_{A 8}=0.893$ was obtained.

The availability of safety belts on the upper births and special facilities for the disabled. In some passenger carriages of the JSC "Lithuanian Railways" ("LG"), the upper berths have special holders, while, in ordinary sleeping carriages, safety belts are available for passengers. Some passenger, diesel and electric trains are adapted for special needs of disabled passengers. The trains have special places for their wheelchairs, as well as toilets adapted for disabled persons and enlarged doorways. The number of such passenger carriages is constantly growing because, when new carriages are purchased or the old ones are modernized, special needs of disabled passengers are taken into account. The wheelchairs with disabled persons are raised to the level of the carriage entrance by mobile hoists, available at large railway stations. The train has six carriages (not including the dining car). In five passenger carriages the upper layer berths are provided with safety belts, though these carriages are not adapted for the disabled. The first carriage has only lower berths, therefore, safety belts are not needed there. This carriage is not adapted for disabled passengers either. The CQI component was calculated by equation (2) and $x_{A 9}=0.333$ was obtained.

Availability of regularly operating shower. Currently, no shower facilities are available in the passenger carriages of the JSC "Lithuanian Railways" ("LG"), though they are urgently needed for both passengers and service staff of international long-distance trains. The CQI component was calculated by equation (2) and the critically low $x_{A 10}=0$ was obtained.

Special compartments for transporting bicycles. The international trains of the JSC "Lithuanian Railways" ("LG") do not have any 
carriages adapted for carrying bicycles. However, the regulations allow for carrying one engineless knocked-down and packed bicycle if there is room for it in a special compartment for hand luggage. In this case, the service is provided to passengers free of charge. The CQI component was calculated by equation (2) and $x_{A 11}=0.50$ was obtained.

Smoking places. The Lithuanian law of tobacco control prohibits smoking of cigarettes (or other tobacco products) in public transport (except for long-distance trains, which should have carriages for smokers and non-smokers). In passenger carriages of international trains of the JSC "Lithuanian Railways" ("LG"), smoking is allowed only in special vestibules. Some passengers object to it because smoke often penetrates through poorly sealed or open doors and gets into the corridor and compartments of the carriage. The experiment was made in the train Vilnius-Moscow to determine the influence of smoking, according to the abovementioned regulations, on travel quality. The CQI component was calculated by equation (2) and $x_{A 12}=0.50$ was obtained.

Radio broadcasting unit and its centralized operation (on/off switching). Volume controls of the train radio are provided in the compartments and corridors of carriages. At present, passengers can also use headphones in the compartments of new carriages made at the plant of railway carriages in Tver (Russia). If headphones are not available in a carriage (because the conductor did not hand them out to passengers), they may listen to the radio if they wish. In these passenger carriages, the radio is switched on and off by the button located in the conductor's compartment, though it cannot be used for volume control. When the train departs from the main station, passengers often ask the conductor to switch off the radio because it is too loud and, therefore, do not hear any information on the route of the train provided by the head of the train. The train has six carriages (not including the dining car). The CQI component was calculated by equation (2) and $x_{A 13}=0.50$ was obtained.

Dining-car (buffet-car). All international trains of the JSC "Lithuanian Railways" ("LG") have dining cars. Strong drinks are served there. For economic reasons, a waiter can be rarely found in the dining car. Usually, selfservice is used or the conductor of a dining car provides the waiter's services. The conductors of passenger carriages offer tea, coffee, soft drinks and pastries to passengers. If a passenger wishes, the conductor should bring him/her the required dish or drink from the dining car. The CQI component was calculated by equation (2) and $x_{A 14}=0.875$ was obtained.

Possibility of calling a conductor to a passengers' compartment in emergency cases. At present, the buttons for calling a conductor to the compartment in the case of emergency cannot be found in all carriages of the train. In all new passenger carriages made at the plant in Tver (Russia), there is a possibility to call a conductor to the compartment. However, push buttons, providing the connection with the conductor, function only if a magnetic card is inserted in the magnetic card reader. Now, these cards are still not available, therefore, passengers cannot call a conductor to the compartment. The train has six carriages (not including the dining car). The CQI component was calculated by equation (2) and $x_{A 15}=0.417$ was obtained.

Possibility of using electrical appliances (hairdryer, iron, etc.). The trains made up in Lithuania do not have any compartments, where passengers could use a hairdryer or an iron. The CQI component was calculated by equation (2) and $x_{A 16}=0.25$ was obtained.

The quality level of the criteria of group $A$, and the respective $x_{A j}$ value based on the real data are presented in Table 2 . The quality level represented by the estimate of the variable $x_{A j}$ is equal to 1 , when it is based on the highest values of the real data, it is equal to 0.5 , when based on the average values, and to 0 , when based on the lowest values of the data.

Using the equation (2), the index $K_{A}$ of the criteria describing the train elements and the technical state of rails (railway track) is calculated as follows:

$$
\begin{gathered}
K_{A}=0.228 \times(0.0411 \times 0.667+0.1035 \times \\
\times 0.473+0.0307 \times 1+0.0716 \times 0.188+ \\
+0.0560 \times 0.786+0.0997 \times 0.964+0.1042 \times \\
\times 0.75+0.0813 \times 0.893+0.0624 \times 0.333+ \\
+0.0709 \times 0+0.0345 \times 0.50+0.0360 \times \\
\times 0.050+0.0450 \times 0.50+0.0822 \times 0.875+ \\
+0.0359 \times 0.417+0.0452 \times 0.25)= \\
=0.228 \times 0.58807=0.1341 .
\end{gathered}
$$




\section{Business Administration and Management}

The index referring to the criteria, describing the elements of the train and the condition of the railway track, was obtained to be $K_{A}=0.134$. The influence of the criteria of group $B$ on CQI $K$ was evaluated by an additive model and $K_{B}=0.099$ was obtained [22]. The influence of the criteria of the groups $C$ and $D$ on CQI $K$ can be evaluated by other additive models, which will be described in further publications.

\section{Fig. 7: Mean weight values $\bar{Q}_{A j}$ of $j$-th criterion of group A, determined by AHP method}

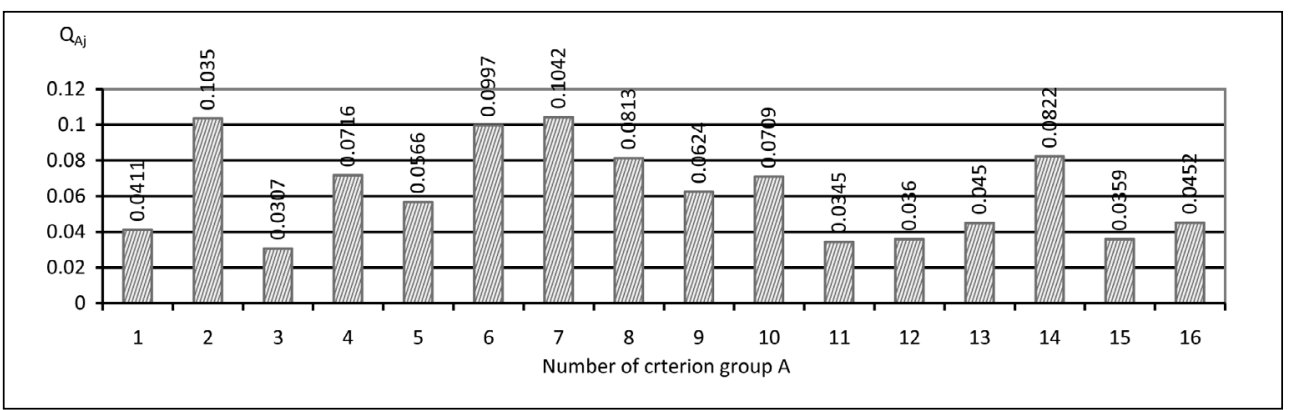

Tab. 2:

Quality level of the criteria of group A and the respective value of the variable $x_{A j}$ based on real data

\begin{tabular}{|c|c|c|}
\hline $\begin{array}{c}\text { Variables } \mathrm{x}_{\mathrm{Aj}} \text { of the } \\
\text { criteria }\end{array}$ & The value of the component & $\begin{array}{l}\text { The } \\
\text { calculated } \\
\text { value } \mathrm{x}_{\mathrm{Ai}}\end{array}$ \\
\hline \multirow[t]{2}{*}{$x_{A 1}$} & $\sum_{s=1}^{36} T Q I_{f s}=903.2 \mathrm{~mm}^{2} ; \mathrm{N}_{\mathrm{km}}=36 ; T \bar{Q} I_{f}=25.09 \mathrm{~mm}^{2}$ & \multirow[t]{2}{*}{0.667} \\
\hline & $T Q I_{f \max }=64.04 \mathrm{~mm}^{2} ; T Q I_{f \min }=14.95 \mathrm{~mm}^{2}$ & \\
\hline \multirow[b]{2}{*}{$x_{A 2}$} & $I_{1}=9 \mathrm{~km}, I_{2}=8 \mathrm{~km}, I_{3}=12 \mathrm{~km}, I_{4}=7 \mathrm{~km}(L=36) \mathrm{km} ;$ & \multirow[b]{2}{*}{0.473} \\
\hline & $\begin{array}{l}v_{\max , I}=120 \mathrm{~km} / \mathrm{h} ; v_{f 1}=43 \mathrm{~km} / \mathrm{h} \quad v_{f 2}=77 \mathrm{~km} / \mathrm{h}, v_{f 3}=57 \mathrm{~km} / \mathrm{h} \\
v_{f 4}=51 \mathrm{~km} / \mathrm{h}\end{array}$ & \\
\hline$x_{A 3}$ & $C E S_{f}=2\left(1,2, \ldots, 7^{*}\right) ; C E S_{\max }=2 ; n_{c a r}=7$ & 1 \\
\hline \multirow[b]{2}{*}{$x_{A 4}$} & $N L_{f}=72 \mathrm{~dB}\left(1,2, \ldots, 6^{*}\right)$ & \multirow{2}{*}{0.188} \\
\hline & $N L_{f}=62 \mathrm{~dB}\left(7^{*}\right) ; N L_{l}=87 \mathrm{~dB} ; n_{c a r}=7$ & \\
\hline$x_{A 5}$ & $C l_{f}=2\left(1,2,3,4^{*}\right) ; C l_{f}=1\left(5,6,7^{*}\right) C l_{\max }=2 ; n_{\text {car }}=7$ & 0.786 \\
\hline$x_{A 6}$ & $V C L_{f}=4\left(1,2, \ldots, 6^{*}\right) ; V C L_{f}=3\left(7^{*}\right) V C L_{\max }=4 ; n_{c a r}=7$ & 0.964 \\
\hline$x_{A 7}$ & $T_{U}=24 ; T_{D}=20 ; \quad \overline{T_{f}}=23 ; \quad n_{c a r}=7$ & 0.75 \\
\hline$x_{A 8}$ & $W C_{f}=4\left(1,2, \ldots, 6^{*}\right) ; W C_{f}=1\left(7^{*}\right) ; W C_{\max }=4 ; n_{\text {car }}=7$ & 0.893 \\
\hline$x_{A 9}$ & $P B_{f}=3\left(6^{*}\right) ; P B_{f}=1\left(1,2, \ldots, 5^{*}\right) P B_{\max }=4 ; n_{c a r}=6$ & 0.333 \\
\hline$x_{A 10}$ & $S_{f}=0\left(1,2, \ldots, 7^{*}\right) ; S_{\max }=2 ; n_{c a r}=7$ & 0 \\
\hline$x_{A 11}$ & $T B_{f}=2 ; T B_{\max }=4$ & 0.50 \\
\hline$x_{\mathrm{A} 12}$ & $S P_{f}=1 ; S P_{\max }=2$ & 0.50 \\
\hline$x_{A 13}$ & $R_{f}=3\left(1,2,3^{\star}\right) ; R_{f}=1\left(4,5,6^{*}\right) ; R_{\max }=4 ; n_{c a r}=6$ & 0.50 \\
\hline$x_{A 14}$ & $D C_{f}=7 ; D C_{\max }=8$ & 0.875 \\
\hline$x_{A 15}$ & $P I_{f}=2\left(1^{*}\right) ; P I_{f}=1\left(2,3,4^{*}\right) ; P I_{f}=0\left(5,6^{*}\right) P I_{\max }=2 ; n_{c a r}=6$ & 0.417 \\
\hline$x_{A 16}$ & $H I_{f}=1 ; H I_{\max }=4$ & 0.25 \\
\hline
\end{tabular}




\section{Conclusions}

The suggested multicriteria model allows for evaluating the quality of travel by train objectively, expressing it by a single value. The value of $K_{A}$, calculated based on the values of the real parameters, allows the authors to state that the considered mathematical model is valid and can be used in practice. The significance of the criteria, describing the train elements and the technical state of rails (railway track) for the comprehensive quality index $K_{A}$, may be evaluated by determining only the variables $x_{A j}$ and using them in the suggested mathematical model.

The highest quality level determined by using the real data was obtained for the criteria A3 (the state of the carriage exterior) $\left(x_{A 3}=1\right)$. The lowest quality level determined by using the real data was obtained for the criteria A10 (availability of regularly operating shower) $\left(x_{A 10}=0\right)$. The average quality level was determined for $A 11$ (special compartments for transporting bicycles) $\left(x_{A 11}=0.50\right), \mathrm{A} 12$ (smoking places) $\left(x_{A 12}=0.50\right)$ and A13 (radio broadcasting unit and its centralized operation) $\left(x_{A 13}=0.50\right)$ based on the real data. First, the real values of the criteria, whose variables $x_{A j}=0$ or are about zero, should be improved. The developed model may be applied to determining the quality or effectiveness of other objects or processes, which can be described by sets of criteria.

\section{References}

[1] CHENG, Y-C., HSU, C-T. Hunting stability and derailment analysis of a car model of a railway vehicle system. Proceedings of the Institution of Mechanical Engineers, Part F: Journal of Rail and Rapid Transit. 2011, Vol. 226, No. 2, pp. 187-202. ISSN 0954-4097.

[2] Dèl didžiausio leistino traukiniu̧ ir lokomotyvu̧ greičio geležinkelio stočiu̧ keliais ir tarpstočiais ( $A B$ "Lietuvos geležinkeliai“ generalinio direktoriaus 2009 m. lapkričio 3 d. ijsakymas Nr. l-843), 2009. Vilnius. $91 \mathrm{p}$.

[3] EGOROV, V.P. Elektrooborudovanie passazhirskikh vagonov. Moskva: Transport. 312 s. 1987.

[4] FURUYA, A., MADANAT, S. Accounting for network effects in railway asset management. Journal of Transportation Engineering. 2013, Vol. 139, Iss. 1, pp. 92-100. ISSN 0733-947X.
[5] HAN, Z., LIU, P. A fuzzy Multi-Attribute Decision-Making method under risk with unknown attribute weights. Technological and Economic Development of Economy. 2011, Vol. 17, Iss. 2, pp. 246-258. ISSN 2029-4913.

[6] HSU, L.R. Cost estimating model for mode choice between light rail and bus rapid transit systems. Journal of Transportation Engineering. 2013, Vol. 139, Iss. 1, pp. 20-29. ISSN 0733-947X. [7] KIM, K., CHIEN, S. Optimal train operation for minimum energy consumption considering track alignment speed limit, and schedule adherence. Journal of Transportation Engineering. 2011, Vol. 137, Iss. 9, pp. 665-674. ISSN 0733-947X.

[8] LAI, Y.-C., BARKAN, C.P.L. Comprehensive decision support framework of strategic railway capacity planning. Journal of Transportation Engineering. 2011, Vol. 137, Iss. 10, pp. 738-749. ISSN 0733-947X.

[9] LAI, Y.-C., LIU, Y.-H., LIN, T.-Y. Development of base train equivalents to standardize trains for capacity analysis. Transportation Research Record. 2012, Vol. 2289, pp. 119-125. ISSN 03611981.

[10] LI, F., GAO, Z., LI, K., WANG, D.Z.W. Train routing model and algorithm combined with train scheduling. Journal of Transportation Engineering. 2013, Vol. 139, Iss. 1, pp. 81-91. ISSN 0733-947X. [11] LIAO, M., LIU, G., QIU, T.Z. Passenger traffic characteristics of service facilities in rail transit stations of Shanghai. Journal of Transportation Engineering. 2013, Vol. 139, Iss. 2, pp. 223-229. ISSN 0733-947X.

[12] LIUJIANG, K., JIANJUN, W., HUIJUN, S. Using simulated annealing in a bottleneck optimization model at railway stations. Journal of Transportation Engineering. 2012, Vol. 138, Iss. 11, pp. 1396-1402. ISSN 0733-947X.

[13] MARTINEZ, E., NELSON, F., PRABHAKARAN, A., JONES, A. Development of the next generation of intercity corridor bi-level equipment with crash energy management. Transportation Research Record. 2012, Vol. 2289, pp. 47-55. ISSN 0361-1981.

[14] MASKELIUNAITE, L. Tarptautinio keleiviu vežimo geležinkeliais proceso kokybès tyrimo daugiatikslis modelis [The model for multicriteria evaluation of the quality of passenger transportation by international trains]: Doctoral dissertation. Vilnius Gediminas Technical University. Vilnius: Technika, 2012. 165 p. ISBN 978-609-457-361-3. [15] MASKELIUNAITE, L., SIVILEVICIUS, H. Applying AHP technique to the assessment of 
railway trip quality (RTQ). In ČYGAS, D., FROEHNER, K.D. (Eds.). Proceedings of the 8th International Conference „Environment Engineering": Selected papers. May 19-20, 2011. Vol. 3. Vilnius: Technika, 2011. pp. 1133-1141. ISSN 2029-7106. [16] MEACHMAN, B.J., DEMBSEY, N.A., JOHANN, M., TUBBS, J., SCHEBEL, K. Simplified approach for assessing initial fire development and spread in passenger rail vehicles. Transportation Research Record. 2011, Vol. 2261, pp. 57-63. ISSN 0361-1981.

[17] Metinè ataskaita [Annual report]. 2012. JointStock Company 'Lithuanian Railways' (AB „,Lietuvos geležinkeliai").

[18] PODVEZKO, V. The comparative analysis of MCDA methods SAW and COPRAS. Inzinerine Ekonomika-Engineering Economics. 2011, Vol. 22, Iss. 2, pp. 134-146. ISSN 1392-2785.

[19] Profesinès rizikos nustatymo kortelè Nr. 9.5. 2005. (AB ,Lietuvos geležinkeliai“ keleiviu vežimo valdyba, Keleivių aptarnavimo poskyris).

[20] SAMENI, M.K., PRESTON, J.M. Value for railway capacity assessing efficiency of operators in Great Britain. Transportation Research Record. 2012, Vol. 2289, pp. 134-144. ISSN 0361-1981.

[21] SIVILEVIČIUS, H., MASKELIŪNAITĖ, L. The criteria for identifying the quality of passengers' transportation by railway and their ranking using AHP method. Transport. 2010, Vol. 25, Iss. 4, pp. 368-381. ISSN 1648-4142.

[22] SIVILEVIČIUS, H., MASKELIŪNAITĖ, L., PETKEVIČIEN, B., PETKEVIČIUS, K. The model of evaluating the criteria, describing the quality of organization and technology of travel by international train. Transport. 2012, Vol. 27, Iss. 3, pp. 307-319. ISSN 1648-4142.

[23] SPERRY, B.R., BALL, K.D., MORGAN, C.A. Cluster analysis of intercity rail passengers in emerging high-speed rail corridor. Transportation Research Record. 2011, Vol. 2261, pp. 31-38. ISSN 0361-1981.

[24] SPERRY, B.R., MORGAN, C.A. Economic impacts of intercity passenger rail service. Evidence from passenger surveys. Transportation Research Record. 2011, Vol. 2261, pp. 25-30. ISSN 0361-1981.

[25] SUN, Y., XU, R. Rail transit travel time reliability and estimation of passenger route choice behaviour. Analysis using automatic fare collection data. Transportation Research Record. 2012, Vol. 2275, pp. 58-67. ISSN 0361-1981.
[26] VALE, C., RIBEIRO, I.M., CALCADA, R. Integer programming to optimize tamping in railway tracks as preventive maintenance. Journal of Transportation Engineering. 2012, Vol. 138, Iss. 1, pp. 123-131. ISSN 0733-947X.

[27] XU, P., SUN, Q., WANG, F. A short-range prediction model for track quality index. Proceedings of the Institution of Mechanical Engineers, Part F: Journal of Rail and Rapid Transit. 2010, Vol. 225, pp. 277-285. ISSN 0954-4097.

[28] YAGHINI, M., AHADI, H.R., BARATI, E., SAGHIAN, Z. Tabu search algorithm for the railroad blocking problem. Journal of Transportation Engineering. 2013, Vol. 139, Iss. 2, pp. 216-222. ISSN 0733-947X.

[29] ZAVADSKAS, E.K., TURSKIS, Z., TAMOSAITIENE, J. Risk assessment of construction projects. Journal of Civil Engineering and Management. 2010, Vol. 16, Iss. 1, pp. 33-46. ISSN 1392-3730.

[30] ZAVADSKAS, E.K., VILUTIENE, T., TURSKIS, Z., TAMOSAITIENE, J. Contractor selection for construction works by applying SAW-G and TOPSIS Grey techniques. Journal of Business Economics and Management. 2010, Vol. 11, Iss. 1, pp. 34-55. ISSN 1648-715X.

[31] HASHEMKHANI ZOLFANI, S., ANTUCHEVICIENE, J. Team member selecting based on AHP and TOPSIS grey. Inzinerine EkonomikaEngineering Economics. 2012, Vol. 23, Iss. 4, pp. 425-434. ISSN 1392-2785.

[32] HASHEMKHANI ZOLFANI, S., REZAEINIYA, N., POURHOSSEIN, M., ZAVADSKAS, E.K. Decision making on advertisement strategy selection based on life cycle of products by applying FAHP and TOPSIS grey: growth stage perspective; a case about food industry in Iran. Inzinerine EkonomikaEngineering Economics. 2012, Vol. 23, Iss. 5, pp. 471-484. ISSN 1392-2785.

Prof. Ing. Henrikas Sivilevičius, Dr.Sc.

Vilnius Gediminas Technical University Dept of Transport Technological Equipment henrikas.sivilevicius@vgtu.It

Assoc. Prof. Lijana Maskeliūnaitè Ph.D. Vilnius Gediminas Technical University Dept of Transport Technological Equipment lijana.maskeliunaite@ vgtu.It 


\section{Abstract}

\section{THE NUMERICAL EXAMPLE FOR EVALUATING THE CRITERIA DESCRIBING THE QUALITY OF THE TRIP BY INTERNATIONAL TRAIN}

\section{Henrikas Sivilevičius, Lijana Maskeliūnaitè}

The paper aims to determine the quality of the trip by train, which depends on the number of factors described by four groups of criteria. Each group includes individual criteria. The weight of the criteria of each group describing the quality of the trip by train is different. It is determined by using Kendall's rank correlation method. The normalized weights of sixteen criteria of the group $A$, describing the elements of the train and the state of the railway track, are found based on the analytic hierarchy process (AHP) method. They are used in the original additive mathematical model, allowing the quality of the trip by train to be expressed by a single value - the multiple criteria index. The weight of each criterion is multiplied by its dimensionless variable calculated by comparing the real criterion value to its best, worst or allowable (standard) value. The validity of the developed mathematical model is checked by using the data on the technical state of the elements of the international train 'Vilnius-Moscow' and the railway track obtained on the territory of Lithuania.

Key Words: Comprehensive quality index (CQI) railway track, track quality index (TQI), additive equation, numerical simulation, practical application.

JEL Classification: CO2, R4, L62, L92.

DOI: 10.15240/tul/001/2014-2-006 